\title{
CRAII DE AZI ȘI DE IERI. O ANALIZĂ COMPARATIVĂ A ROMANELOR IERBAR DE ANDREI DÓSA ȘI CRAII DE CURTEA- VECHE DE MATEIU CARAGIALE
}

\section{CĂTĂLINA SUDITU}

\section{Universitatea „AL. I. Cuza”, Iași}

Abstact: On the back cover of Andrei Dósa's first novel, Ierbar, Alexandru Vakulovski, a Moldavian writer and literary critic, highlights the (possible) connection between the characters in Dósa's text and the decadent (anti)heroes from Mateiu Caragiale's Craii de Curtea-Veche. Proposing a lucid walk on the reading path opened by Vakulovski, the current paper aims to present a comparative study of the two novels published at a time distance of ninety years to explore the level of kinship on which the narrative actants from the mentioned books are positioned, as well as the similarities and differences of the social, political and economic context in which they are living.

Keywords: comparative reading, Decadentism, narcotics, crisis

Pe coperta a patra a romanului de debut aparţinând lui Andrei Dósa, Alexandru Vakulovski îi apropie pe protagoniștii Ierbarului de craii mateini ${ }^{1}$, orientând astfel pe (posibilul) cititor către o lectură în care, în mod mai mult sau mai puţin conștient, acesta va tinde să vadă în cartea publicată în anul 2019 de către Polirom un fel de adaptare pe fundal contemporan a întâmplărilor din Craii de Curtea-Veche. Pășind cu luciditate pe calea de lectură propusă de către criticul basarabean, voi încerca să realizez o lectură comparativă a celor două romane, pentru a vedea în ce măsură personajele acestora sunt înrudite.

1. Ibidem, p. 145 
Atât pentru prima, cât și pentru cea de-a doua ediţie a cărţii lui Dósa, a fost folosită drept imagine de copertă o pictură aparţinând lui Henri Rousseau, imagine aleasă de către autor și al cărei stil se asociază (chiar și necunoscând vreun fel de informaţie despre pictor) (neo)primitivismului. Această alegere ar putea părea, la o privire inițială, una destul de stranie, considerând că mediul în care îş̦i petrec timpul protagoniştii cărţii este prin excelenţă unul artificial, construit, fie că ne referim la living(ul regizorului), la bar, la azilul de bătrâni sau la Dragonul Roșu (în felul său un rai al artificialităţii și al kitschului), fie că avem în vedere orașul ca suprastructură ce include toate spaţiile deja menţionate. Totuşi, dacă ne gândim la sintagma junglă urbană, consacrată în prima parte a secolului al XX-lea,şi cu atât mai valabilă în spaţiul românesc astăzi, în plină explozie a dezvoltării urbane de tip capitalist, devine mai ușor de întrezărit legătura dintre imagine și text.

Cei cinci crai din Ierbar sunt locuitori ai Bucureștiului la început de mileniu trei, un București în care capitalismul s-a instalat peste blocurile anoste, deprimante, proliferând prin hipermarketuri si mall-uri (cu toata gama lor nesfârșită de produse care înnebunesc simţurile şi cu tot plasticul pe care îl revarsă în jur în cascade ) reclame, maşini ș.a.m.d. Impactului acestui cadru tipic modern asupra individului i se adaugă efectele de diminuare a atenţiei și de dependenţă de nou determinate de (hiper)utilizarea noilor tehnologii, internetul ocupând un rol principal. Trăind mai degrabă într-un simulacru ${ }^{2}$ al realitătii decât în realitate, personajele din ierbar se confruntă și cu ceea ce am putea numi drept o junglă mentală, în care fauna este compusă din o varietate de probleme legate de identitate- le este greu să își dea seama ce le place și ce nu, ele întâmpină dificultatea închegării unei imagini coerente despre sine, care se sparge în numeroase fragmente, fapt care are în mod implicit și efecte asupra relaţiei cu celălalt.

În acest context, drogurile și, în primul rând, iarba, sunt utilizate ca încercare disperată de (re)conectare, în manieră ritualică, a individului la aici și acum, ca timp și spațiu primordiale. Ceea ce resimt (dramatic) personajele e nostalgia Omului și a lumii-reale, aflată într-o relație dialectică cu lumea-simulacru. Fiecare dintre ele încercă, prin (auto)bombardarea simțurilor, obținerea unor stări de maximă intensitate, indiferent de felul acestora- uneori plăceri morbide și dureroase, ca în timpul vizitelor la azilul de bătrâni, alteori marcate de fascinaţie halucinatorie, cum se

2. Ibidem, p. 69 
întâmplă în timpul expediţiei în grup la Dragonul Roșu, stări care le-ar garanta, dacă nu accesul la Prezent, cel puţin anestezia.

$\mathrm{Nu}$ oricine poate face parte din grupul celor care experimentează conectarea la Real(itate). În această privință, cei cinci amici alcătuiesc un fel de sectă, la care au acces numai cei aleși. E un proces care ține seama de intuiția celor care fac selecția, de moodul general al momentului în care ea se petrece, dar și de o anumită inițiere în tema drogărelii pe care nou veniții trebuie să dovedească că au traversat-o deja prin utilizarea unui limbaj tipic, care include cunoaşterea unor eufemisme cât mai variate pentru joint sau pentru starea de după consumarea lui (vărzeală, praf etc.), dar și printr-o sumă de gesturi specifice (precum îndemânare la rulat). De asemenea, trebuie să existe o legătură de natură culturală între posibilii aleși și grupul care deține puterea (cel puțin atât cât deține iarba), legătură ce are la bază anumite preferințe muzicale, cinematografice, literare.

Revenind la nivelul lingvistic, romanul semnat de Dósa este încărcat de cuvinte și expresii provenite din spațiul anglofon, unele preluate ca atare (trip, flow, curbă slow-down, vibe), altele calchiate (cel mai bun exemplu fiind cel oferit de manuț/menuți), tangența cu acest spațiu reprezentând un must pentru oricine își dorește să calce în sufrageria-ierbar. Rolul proaspeților admiși în livingul spațiu de cult e unul clar definit, ei trebuie să asculte cu devoțiune, să ne râdă glumele, iar când vibe-ul e anibilat de aerul fierbinte și leneș ce trece peste savană, să propună lucruri mișto cu jumătate de gură, timid, invitându-ne parcă să le perfecționăm (p. 11). Important e să se reușească menţinerea unei atmosfere mellow, psychedelic, cinematic and tasteful(p.29).

Întorcându-ne privirea către Craii de Curtea-Veche, și aici avem de a face cu substanțe care au efect asupra creierului, și, implicit, a stării, alcoolul fiind principala dintre ele. Dacă prin consumul de substanțe psihoactive personajele din Ierbar doreau să se ancoreze în Prezent, (anti) eroii mateini sunt consumatori tocmai pentru că alcoolul învăluie lumea într-o pojghiţă obscurizantă, poziţionându-i în zona de graniţă dintre real și imaginar. Ei sunt animale de noapte într-o pădure urbană căreia îi cunosc toate ascunzișurile și care le dă senzația de confort prin efectul de umbră, efect ce le permite retragerea în visare într-un alt timp și întrun spațiu străin. Plasate la final de Belle Epoque, întâmplările din Craii de Curtea-Veche aduc în prim plan figura unor indivizi în care domină nostalgia după altcândval altundeva (excepţie făcând Pirgu, a cărui existenţă, orientată către construcţia unui viitor de succes, pune, prin contrast, și mai mult în evidenţă predispoziţiile celorlalți), aflat într-un 
raport de antiteză cu un prezentul degrada(n)t, lipsit de farmec, cu care niciunul dintre cei patru crai nu are o relație prea bună și pe care îl detestă, simţindu-se urmăriţi de sentimentul ratării. Ratarea plutește și în aerul pe care îl inhalează, îmbibat în miros de iarbă, Gabi, scriitorul, filozoful, hackerul și regizorul. Ceea ce se cere subliniat este că în cele două cazuri cauzele ratării sunt extrem de diferite.

Atunci când ne referim la protagoniștii din Craii de Curtea-Veche, avem de a face, după cum o subliniază și Ovid S. Crohmăniceanu, cu decrepitudinea morală și eșecul cultivate ca trăsături distinctive ${ }^{3}$, asumate cu o plăcere masochistă de primă clasă. Pentru narator, la fel ca și pentru Pirgu și Pașadia, ratarea se află conectată cu apatia și blazarea, transformate în mărci ale nobleţei și ale filonului aristocratic. Ratarea e, prin urmare, o chestiune de alegere. Ei se cunosc pe sine (chiar dacă rămân învăluiţi într-o manta de mister pentru cititor, care nu are acces decât parţial la dosarul lor de existenţă, ale cărui file nu poate ști niciodată cu siguranţă dacă spun adevărul sau dacă au apărut din imaginaţie), și mai ales cunosc foarte bine cine vor să pară că sunt. Menţinerea strălucitoare a aurei lor de distincţie, o aură cultivată în mod conștient, presupune și include un amestec de rafinament, inteligenţă (fie ea câștigată din cărţi sau din contactul direct cu lumea) și auto-degradare, estetizată și ridicată la rang de artă. Plictisul, târârea în mocirla zonelor cele mai obscure ale vieţii este o condiţie sine qua non a statutului pe care vor să şi-l menţină, chiar cu preţul vieţii (tocmai pentru că fără el viaţa nu ar mai avea niciun sens). Vorbind despre personajele romanului lui Mateiu Caragiale, Ovid. S. Crohmăniceanu punctează:

Trebuie să observăm însă imediat încă ceva: nu noblețea de neam, propriu-zisă, ţine să se distanţeze prin comportările „crailor”, ci o „stirpe” a celor care știu să-și croiască prin însusiri aparte, ei singuri, calea spre mărire si să formeze o castă.

Dacă încercăm să vedem cu cine anume le plăcea „crailor” să hoinărească, in lungile lor visuri, pe la curtile princiare, de-a lungul secolului XVIII, „cel mai frumos dintre veacuri”, "veacul binecuvântat”, "veacul cel din urmă, al bunului plac și al bunului gust", vom avea o surpriză. Lista obţinută cuprinde nume ca: Theodor von Neuhof, Claude Alexandre de Bonneval, Cantacuzen, Isabella Tarakhanova, Elisabeth Chudleigh, ducesă de Kingston, Charles ele Beaumont d'Eon, Stefan Zanovici, Friedrich von der Trenck,

3.În sensul pe care Jean Baudrillard îl dă termenului. Vezi Jean Baudrillard, Simulacre și simulare, IDEA Design \& Print, Cluj, 2008. 
conte de Saint-Germain, Giuseppe Bal-samo, conte de Cagliostro, JohannGeorg Schrepfner, Casanova. Ca și cel al lui Barry-Lindon, ele nu aparţin, niciunul, aristocraţiei autentice. Toate au fost purtate de niște aventurieri, iar particula nobiliară și-au adăngat-o numelui ei singuri sau au obținut-o pe căi necurate. ${ }^{4}$

Pentru Pirgu, Pașadia și pentru narator rolul evadării din prezent în povești(le trecutului) este, deci, același pe care îl au și alcoolul și vizitele la casa Arnotenilor; ele reprezintă hrană pentru iluzia propriei distincţii, iar dacă aleg să călătorească cu gândul în istorie și pe pământurile exotice ale unor ţări străine, o fac tocmai pentru că de acolo își extrag măștile. În ciuda faptului că întreaga lor viaţă are configuraţia unui joc al aparenţelor, tocmai acest joc este cel care dă, în mod paradoxal, vieţii un scop și o face să merite să fie trăită.

De ce este totuși necesară josnicia și decăderea morală în constituirea imaginii aristocratice? Răspunsul ţine de momentul în care sunt plasate evenimentele. La sfârșit de secol al XIX-lea, semnele schimbărilor sociale care ţin de modificarea structurilor de putere dominante sunt deja mai mult decât evidente, familiile (cu adevărat) de viţă nobilă își pierd din influenţă și presimţirea dispariţiei atrage de la sine slăbiciunea, tentaţia autodistrugerii. ${ }^{5}$ Personajele din Craii de Curtea-Veche nu fac altceva decât să se comporte în conformitate cu vremurile pe care le trăiesc.

La capătul diametral opus, tocmai sensul este cel care lipsește existenţei personajelor din romanul lui Dósa, iar în lipsa sa, ele nu își pot construi nici identitatea. Nici unul dintre cei cinci crai din Ierbar nu știe exact cine este, cunoscând numai diferite variante ale persoanelor care par a fi, pentru că lumea în care ei se învârt se caracterizează printr-un spectacol al aparenţelor aflate într-o permanentă schimbare, aparenţe având un capital simbolic a cărui valoare se modifică mereu, după un sistem imprevizibil. Sentimentul ratării își are originea tocmai în această imposibilitate de a se cunoaște pe sine și de a-și înţelege poziţia în lume. Senzaţia de alienare, de tristeţe copleșitoare, se vrea vindecată, așa cum spuneam, prin ancorarea într-un prezent hiperintens care să topească totul, un prezent-veșnic, fascinant, un timp suspendat în care fiinţa să se simtă reconectată la lume într-o stare asemănătoare cu aceea resimţită de copil în uterul matern, stare de bine în care problemele identităţii și sensului nu s-au ridicat

4.Ibidem, p. 220.

5. Vezi Angelo Mitchievici, Decadență și decadentism, , Decadență și decadentism, Editura Curtea Veche, București, 2011. 
încă, copilul existând pur și simplu: Uneori am impresia că (...) acţiunile noastre sunt pe alint. Ne alintăm adicţia, ne alintăm cu gândul la veșnicie, suspendaţi in plăcere și uitare (p.7)

Vindecarea se dovedește însă temporară și tocmai de aceea iluzorie, căci uitarea provocată de droguri e precedată de aducerea aminte a imposibilităţii de a pune ordine în gânduri, de a crea un sistem valoric stabil, de a da, cu alte cuvinte, un sens, adâncind de fapt fiinţa în confuzie în raportul său cu sine, cu celălalt, cu viaţa în general, și, nu în ultimul rând, în acela cu moartea, pe care nu are habar cum să o trateze, dar care o sperie. Soluţia pe care naratorul-personaj o oferă tuturor acestor probleme, prezentată încă de pe prima pagină a romanului, nu anulează tragicul situaţiei, însă îl înmoaie într-o manieră existenţialistă:

Tot ce trebuie să fac e să-mi accept eșecul și să văd în ce l-aș putea transforma. Dar ca să pot să-l pot accepta, trebuie mai întâi să vorbesc despre el. Măcar așa, episodic și vag, atât cât îmi mai permite creierul acesta varzăa, atât cât îmi permit plictiseala și lehamitea care se furișează in orice proiect al meu (p.7)

Așadar, încă de la început cititorul e invitat să privească cele relatate ca pe niște materiale rezultate în urma unei ședinţe de (auto)terapie. Așa cum membrii sectei constituite în jurul sufrageriei își selectează musafirii, romanul însuși (în același timp veritabil metaroman ${ }^{6}$ ) își triază de la început cititorii, prin limbajul pe care îl folosește, prin tema pe care o propune, dar mai ales prin scopul scrierii sale declarat de către regizorulnarator. De ce ar dori cineva să citească o carte despre o gașcă de drogaţi și despre ratare? Pentru că, din fericire, ea funcţionează ca terapie şi în

6. Pe lângă intenţia de a scrie un roman precizată încă de pe prima pagină, cartea cuprinde un dialog cheie pentru înţelegerea felului în care o carte (oricare carte) ar trebui să fie scrisă pentru a fi citită de către tinerii de astăzi, cititorii doriți și de către romanul lui Dósa. Astfel, în capitolul Năvălirile barbare, suntem puși în faţa unei discuţii cu caracter de mise en abyme, în cadrul căreia deslușim conturul Ierbarului și al intenţiilor sale:

- Sunt foarte curios ce părere ai despre toată chestia asta. Mai poate textul scris să stârnească adicţie în rândul puștimii? Cum ar trebui să arate? (...)

- Poate ar trebui să ne concentrăm pe durerea întâlnirii nemediate, visceral, cu un mediu aseptic? E ceva aici care strigă: hei, suntem prizonierii pompelor medicale, transvazaţi dintr-un aparat în altul și cam asta e viaţa. Lichidele corporale ne părăsesc, încetul cu încetul. Un roman despre pătrunderea în organism a unor corpuri străine care încearcă să ne prelungească viaţa, dar care de fapt ne jenează teribil. Un fel de Pynchon, dar cu accentul pus pe frica de îmbătrânire. Un Pynchon gerontofob (p.33) 
sens invers. Ierbar este un roman dedicat tuturor celor care simt că nu reușesc să găsească un sens, că acest sens nu mai există, sau că există într-o substanţă fluidă care curge mult prea rapid prin organismul social pentru a mai putea fi prinsă; nu pentru că ar oferi vreo soluţie, ci din simplul motiv că explorând hăul, îţi dă iluzia că ești mai puţin singur. Din această categorie, sugerează textul, fac parte mai ales tinerii, cei născuți după anii '80, bulversați, nesiguri, bombardați cu informație.

Atât Ierbar, cât și Craii de Curtea-Veche reprezintă, prin problematica pe care o tratează și prin personajele pe care le înfăţișează, romane ale timpului lor. Dacă există o asemănare între craii mateini și cei cinci protagoniști ai cărţii lui Andrei Dósa, ea ţine de manifestarea concretă a unor comportamente care au origini și semnificaţii foarte diferite, prin urmare sintagma adaptare utilizată la începutul lucrării trebuie privită ca o exagerare. Consumul de droguri, viaţa trăită ca un party, anxietatea și apatia sunt comune ambelor cărţi deoarece fiecare dintre ele surprinde cu acurateţe o perioadă de criză a omului și a valorilor sale. Dacă în Craii de Curtea-Veche viaţa se salvează prin jocul aparenţelor, în Ierbar tocmai acest joc provoacă drama personajelor. 


\section{Bibliografie primară}

Dósa, Andrei, Ierbar, Iași, Editura Polirom, 2019.

Caragiale, Mateiu, I., Craii de Curtea-Veche, București, Editura Tineretului, 1968.

\section{Bibliografie teoretică}

Baudrillard, Jean, Simulacre și simulare, Cluj, Editura IDEA Design \& Print, 2008.

Crohmăniceanu, Ovid, Cinci prozatori în cinci feluri de lectură, Călărași, Editura Cartea Românească, 1984,

Mitchievici, Angelo, Decadență și decadentism, București, Editura Curtea Veche, 2011. 